\title{
ALGUNAS REFLEXIONES PARA LOS ESTUDIANTES DE MEDICINA
}

\section{Laurentino BARRIOS ${ }^{1}$.}

${ }^{1}$ Profesor Titular de Semiología Médica, Decano y Presidente del Consejo Directivo, Facultad de Ciencias Médicas, Universidad Nacional de Asunción, San Lorenzo - Paraguay.

Cómo citar este artículo: Barrios L. Algunas reflexiones para los estudiantes de Medicina. Medicina Clínica y Social. 2017;1(1):4-6.

Es una gran distinción como Decano poder dirigirme a los estudiantes de Medicina, no sólo de la Universidad Nacional de Asunción sino también de otras Universidades, en el lanzamiento de este primer número de la Revista Medicina Clínica y Social. A través de estas líneas quisiera hacer hincapié en algunos puntos, y algunas reflexiones, que considero importantes en su rol como estudiantes de Medicina.

\section{- Relacionamiento con compañeros y docentes}

Un ambiente de buen relacionamiento y cordialidad es crucial para mejorar el proceso de enseñanza-aprendizaje y para facilitar la convivencia diaria en la Universidad. Por ello, les animo a participar activamente de la vida universitaria, mas esta participación se debe dar en el marco del respeto mutuo de los involucrados, así como a los marcos normativos institucionales.

- Habilidades de comunicación con el paciente y su familia

Una capacidad importante del médico en formación es su capacidad de comunicarse, no sólo con sus profesores y compañeros, sino fundamentalmente con los pacientes y sus familiares. Esta capacidad debe ser desarrollada desde el inicio mismo de la carrera, a fin de asegurar una correcta comprensión del mensaje que queremos transmitir a nuestros pacientes.

El desarrollo de habilidades eficaces de comunicación es clave en diversos momentos de la atención a un paciente. Por ejemplo, una clara comunicación es importante en los traspasos de guardia de urgencias y en la terapia intensiva, a fin de asegurar que la información sobre los pacientes sea correctamente comprendida por los colegas. De esta manera se evitarán la mala praxis y otras complicaciones.

- Puntualidad y responsabilidad

Estas virtudes deben ser cultivadas siempre, pues realmente marcarán su desempeño académico, y seguidamente, su desempeño como médicos.

La puntualidad y responsabilidad son elementos esenciales de todo buen médico, y hacen de éste una persona comprometida con la institución donde trabaja, reconocido así por sus profesores, colegas y pacientes. Si como médicos deseamos que nuestros pacientes cumplan y se adhieran a los tratamientos que les prescribimos, que sea puntuales en sus controles y 
responsables en el cuidado de su salud, nosotros entonces debemos ser los primeros en dar el ejemplo, siendo puntuales en la asistencia a nuestras clases y entrega de trabajos, y responsables en el estudio diario.

\section{- Manejo del estrés psicosocial}

El estrés psicosocial, propio de la vida universitaria, es muchas veces enemigo del buen rendimiento académico. Este estrés puede manejarse toda vez que logren organizar su tiempo de estudio, cumplir con sus tareas y dedicar las horas necesarias a la lectura. Una buena organización del estudio es crucial para poder hacer frente al estrés; y ello les permitirá inclusive poder tener tiempo para otras actividades como el ejercicio, los deportes y el cultivo de relaciones sociales, así como de su propio estilo de vida.

\section{- Crecimiento hacia la autonomía}

Los estudiantes de Medicina muchas veces se van encontrar con la necesidad de tomar decisiones e iniciativas y no ser meros receptores de conocimientos. Su misión, por lo tanto, es la obligación de asumir la responsabilidad principal de estudiar y cumplir sus responsabilidades frente a sus profesores, con las obligaciones de las cátedras, pero también de ser permeables y atentos del mundo que les rodea.

Lograr ser autodidactas en su desempeño es clave para comprender el difícil arte de la medicina. Por ello, desde los primeros años de la carrera, es importante "aprender a aprender", es decir a encontrar las mejores técnicas de estudio que se adapten a sus necesidades, y a lograr establecer una disciplina en el estudio.

La información que ustedes incorporen durante su carrera les durará aproximadamente 5 años luego de egresar. Por ello, es crucial que hayan aprovechado la oportunidad y hayan "aprendido a aprender", para lograr así mantenerse actualizados y en constante crecimiento profesional.

\section{- Responsabilidad Social}

Como estudiantes de Medicina es su responsabilidad devolver al pueblo paraguayo lo que se invierte en la educación de cada uno de ustedes. Esta devolución será posible toda vez que cumplan con su compromiso de formarse correctamente. La responsabilidad social no debe confundirse con "ayuda social", sino con el involucramiento de los estudiantes de Medicina, de manera holística, en la promoción, prevención, diagnóstico, tratamiento y recuperación de la salud.

Finalizando, quisiera insistir en que no es el conocimiento lo único que deben adquirir en la carrera, sino que deberán construir con sus docentes, su identidad como estudiantes de Medicina y futuros médicos, esa identidad que surge de la excelencia, en todos los aspectos, de la responsabilidad frente a las demandas de la sociedad, del pensamiento crítico que tiende a modificar las situaciones mejorándolas, del cultivo de los valores, de la libertad de pensamiento, y de la creatividad que necesitan de la honestidad intelectual, de la verdad y del respeto mutuo (1). 
Les auguro lo más grandes éxitos en su carrera. Como su Decano estaré acompañándolos y brindaré todo de mí para que su viaje a través del grado llegue a buen puerto.

\section{CONFLICTOS DE INTERÉS Y FUENTE DE FINANCIACIÓN}

El autor declara no poseer conflictos de interés. Fuente de financiación: ninguna.

\section{REFERENCIAS BIBLIOGRÁFICAS}

1. Universidad Nacional de Santiago del Estero [Internet]. Santiago del Estero: Discurso de inicio de la carrera de Medicina. [Citado el 26 de abril de 2017]. Disponible en: https://www.unse.edu.ar/archivos/DISCURSO\%20DE\%20INICIO\%20DE\%20LA\%20CAR RERA\%20DE\%20MEDICINA.pdf 


\section{SOME REFLECTIONS FOR MEDICAL STUDENTS}

\section{Laurentino BARRIOS ${ }^{1}$.}

${ }^{1}$ Senior Professor of Medical Semiology, Dean and Chairman of the Board of Directors, School of Medical Sciences, National University of Asunción, San Lorenzo - Paraguay.

How to cite this article: Barrios L. Algunas reflexiones para los estudiantes de Medicina. Medicina Clínica y Social. 2017;1(1):4-6.

It is a great distinction as Dean to address medical students, not only from the National University of Asunción but also from other Universities, at the launch of this first issue of the Journal Medicina Clínica y Social. Through these lines, I would like to emphasize some points, and some reflections, which I consider important for medical students.

- Relationship with classmates and professors

An atmosphere of good relationship and cordiality is crucial to improve the teaching-learning process and to facilitate daily living in the university. Therefore, I encourage medical students to actively participate in the university life; but this participation should be driven by a mutual respect of those involved and for the institutional regulatory frameworks.

- Communication skills with the patient and his/her family

An important capacity of a medical doctor trainee is his/her ability to communicate, not only with his/her professors and peers, but mainly with patients and their families. This capacity must be developed from the very beginning of the undergraduate program, in order to ensure a correct understanding of the message we want to convey to our patients.

Developing effective communication skills is key at various times of patient care. For example, clear communication is important in emergency room transfers and in intensive care, to ensure that colleagues correctly understand patient information. This will avoid malpractice and other complications.

\section{- Punctuality and responsibility}

These virtues must always be cultivated, as they will really mark the academic performance of medical students, and then their performance as medical doctors.

Punctuality and responsibility are essential elements of all good medical doctors, and make them committed persons with the institution where they work, recognized by their professors, colleagues and patients. If as medical doctors we want our patients to comply with and adhere to the treatments that we prescribe, to be timely in their controls and responsible for their health care, we should then be the first to set the example, being punctual in attending our classes and delivery of jobs, and responsible in the daily study. 
- Management of psychosocial stress

Psychosocial stress, typical of university life, is often an enemy of good academic performance. This stress can be managed whenever medical students are able to organize their study time, accomplish their tasks and spend the necessary hours to read. Good study organization is crucial to coping with stress; this will allow them to even have time for other activities such as exercise, sports and the culture of social relationships, as well as their own lifestyle.

\section{- Growth towards autonomy}

Medical students will often find themselves faced with the need to make decisions and initiatives and not be mere recipients of knowledge. Their mission, therefore, is the obligation to assume the primary responsibility of studying and fulfilling their responsibilities to their professors, to the duties of the departments, but also to be permeable and attentive to the world around them.

Being self-taught in their performance is key to understanding the difficult art of medicine. Therefore, from the first years of the undergraduate program, it is important to "learn to learn", that is, to find the best study techniques that suit their needs, and to establish a discipline in the study.

The information that medical students incorporate during the undergraduate program will last approximately 5 years after their graduate. For this reason, it is crucial that they have seized the opportunity and "learned to learn", in order to keep themselves updated and in constant professional growth.

- Social responsibility

As medical students, it is your responsibility to give back to the Paraguayan people what is invested in the education of each one of you. This return will be possible whenever you fulfill your commitment to be correctly form. Social responsibility should not be confused with "social assistance", but with the involvement of medical students, holistically, in the promotion, prevention, diagnosis, treatment and recovery of health.

Finally, I would like to emphasize that it is not only knowledge what medical students must acquire during the undergraduate program; they also must build with their professors, their identity as medical students and future medical doctors. That identity arises from excellence, in all aspects, from responsibility towards the demands of society, from critical thinking that tends to change situations by improving them, from cultivating values, freedom of thought, and from the creativity they need from intellectual honesty, truth and mutual respect (1).

I wish you the greatest successes in your career. As your Dean, I will be accompanying you and I will provide everything from me so that your journey through the undergraduate program reaches a good point.

\section{CONFLICTS OF INTEREST AND FUNDING}

Conflicts of interest: none. Funding source: none. 


\section{REFERENCES}

1. Universidad Nacional de Santiago del Estero [Internet]. Santiago del Estero: Discurso de inicio de la carrera de Medicina. [Cited 26 April 2017]. Available at: https://www.unse.edu.ar/archivos/DISCURSO\%20DE\%20INICIO\%20DE\%20LA\%20CAR RERA\%20DE\%20MEDICINA.pdf 